\title{
Pengaruh Bermain Gagdet Terhadap Perkembangan Emosional Anak Usia Dini
}

\author{
Rika Yuliani Putri, Nur Hazizah \\ Pendidikan Guru Pendidikan Anak Usia Dini \\ Fakultas Ilmu Pendidikan \\ Universitas Negeri Padang
}

\section{Rikayp610@gmail.com}

\begin{abstract}
Abstrak
Artikel ditulis ini bertujuan untuk mengetahui bagaimana pengaruh gadget terhadap perkembangan emosi anak usia dini, dari pembahasan tersebut ternyata penggunaan gadget terhadap anak usia dibawah 12 tahun banyak berdampak negative untuk perkembangan emosional dan sosial anak, yaitu terganggunya mental, emosi yang tidak stabil, hubungan emosional antara orangtua dan anak akan terhalang serta hubungan sosial anak terhambat disebabkan oleh fitur-fitur dan aplikasi games yang terdapat pada gadget.

Untuk meningkatkan dan memaksimalkan seluruh aspek perkembangan anak terutama aspek sosial emosional, perlu kerjasama orangtua dirumah dan guru disekolah dengan membatasi anak usia dini dalam menggunakan gadget dan melibatkan mereka dalam interaksi dengan lingkungan sehari-hari, agar anak-anak memiliki kemampuan untuk bekerjasama, beradaptasi, berinteraksi secara positif, mampu mengendalikan emosi diri,mengembangkan rasa mepati terhadap teman, mematuhi aturan dan menghargai oranglain dimana semua itu adalah modalnya sebagai makluk sosial.
\end{abstract}




\section{BAB I \\ PENDAHULUAN}

A. Latar Belakang Masalah

Anak usia dini berada pada masa pertumbuhan dan perkembangan maka sangat penting penting bagi kita sebagai orang tua untuk memperhatikan tingkah laku serta emosional anak agar anak bisa tumbuh sesuai dengan tahapan usia nya. Penggunaan gadget pada anak usia dini dapat mengganggu kosentrasi belajar anak. Gadget memiliki fitur-fitur yang canggih seperti kamera, games online yang membuat anak kecanduan terhadap games tersebut.

Selain itu, penggunaan gadget menyebabkan kurangnya interaksi sosial. Anak usia dini secara umum menghabiskan waktunya dengan bermain dan mencoba hal- hal yang baru. tidak jarang mereka bermain dan memuaskan rasa penasaran mereka melalui gadget. Di era modern ini anak anak jauh lebih senang menghabiskan waktunya dengan gadget, bukan bermain dengan teman sebayanya.

Dalam proses perkembangan emosional anak, orang- orang yang ada disekitar anak baik orang tua, guru dan masyarakat turut serta dalam membantu, mengontrol dan mengarahkan emosional anak usia dini. Oleh karena itu, orang tua, guru dan masyarakat perlu kiranya mengetahui tentang emosional anak usia dini, karakteristik dari perkembangan emosional dan banyak hal lainnya tentang emosional anak yang akan menjadi pedoman dalam mengembangkan emosional anak. Maka dari itu, dalam artikel ini akan membahas mengenai Pengaruh Gadget Terhadap Perkembangan Emosional Anak Usia Dini.

B. Rumusan Masalah

Dari latar belakang di atas maka dapat dirumuskan permasalahannya yaitu bagaimana Pengaruh Gadget Terhadap Perkembangan Emosional Anak Usia Dini dan Bagaimana Peran Guru dan Orang Tua Untuk Meminimalisir Dan Mengurangi Dampak Negatif Dari Penggunaan Gadget Terhadap Anak Usia Dini.

C. Tujuan Penulisan

Untuk mengetahui bagaimana perkembangan aspek emosional anak serta bagaimana cara guru dalam mengatasi anak yang mengalami gangguan emosi yang disebabkan oleh penggunaan Gadget yang berlebihan dirumah 


\section{BAB II \\ KAJIAN TEORI}

A. Hakikat Emosi Anak Usia Dini

1. Pengertian Emosi

Emosi adalah perasaan yang ada dalam diri kita, dapat berupa perasaan senang atau tidak senang, perasaan baik atau buruk. Dalam world book dictionary (1994:690) emosi didefinisikan sebagai "berbagai perasaan yang kuat". Perasaan benci, takut, marah, cinta, senang, dan kesedihan. Macam-macam perasaan tersebut adalah gambaran dari emosi. Dari pengertian semosi tersebut dapat penulis simpulkan bahwa, setiap individu tentunya pasti memiliki setiap macam dari perasaan emosi tersebut, tergantung dari invidu itu sendiri dan orang disekitarnya dalam mengontrol dan menyikapi dari berbagai emosi yang timbul dari masing-masing individu tersebut.

Menurut (Golmen, 1995), didalam buku Emosi Anak Usia Dini karangan Riana Mashar pada tahun 2015, bahwa emosi adalah perasaan amarah, ketakutan, kebahagiaan, cinta, rasa sedih. Jadi dapat disimpulkan bahwa emosi itu sendiri yaitu perasaan yang ada pada diri baik itu sedih bahagia, senang dan sebagainya yang akan dikembangkan melalui perkembangan kepribadian anak usia dini. Menurut penulis, jika pendidik dan orangtua sendiri memiliki kecerdasan emosional yang baik dan dapat dikontrol, maka tidak terkecuali dapat di terapkan kepada anak usia dini agar memiliki kecerdasan emosional yang baik dan stabil dengan bantuan pendidik dan orangtua.

2. Perkembangan Emosi Pada Anak Usia Dini.

Menurut ( Hurlock, 1991), didalam buku Emosi Anak Usia Dini karangan Riana Mashar tahun 2015, Hurlock menyatakan 2 macam emosi yang paling umum terjadi pada anak usia dini yaitu ketakutan dan kemarahan. Menurut penulis, kedua bentuk emosi tersebut adalah bentuk dari macam-macam emosi negative, dimana saat anak merasa takut mereka meluapkanya dengan cara menangis dan berteriak bahkan ada yang pingsan saat merasa sangat ketakutan dan melemparkan barang, memukul dan menyakiti dirinya sendiri saat marah.

Perkembangan emosional anak termasuk mengenali apa perasaan dan emosi yang mereka alami, mengerti bagaimana dan mengapa hal itu terjadi, mengenali perasaan sendiri dan orang lain, dan mengembangkan cara yang efektif dalam mengelolanya. Seiring dengan pertumbuhan anak, perkembangan emosionalnya juga akan menjadi semakin kompleks tergantung dengan pengalaman yang didapatkannya. Karena itulah, pendidik dan orangtua dirumah mengembangkan kemampuan untuk mengelola emosi akan menjadi hal yang sangat penting untuk kesehatan mental anak.

Sedangkan menurut (Walgito, 1997) mengemukakan 3 teori emosi yaitu :

a. Teori sentral, dimana yang kita ketahui bahwa teori sentral merupakan gejala kejasmanian akibat dari emosi yang dialami oleh undividu.

b. Teori peripheral, yaitu dimana gejala gejala kejasmanian bukanlah merupakan akibat dari emosi yang dialami individu..

c. Teori kepribadian, diaman emosi ini adalah suatu kegiatan individu tidak dapat dipisahkan antara jasmani dan psikis sehingga emosi dikatakan suatu perubahan kejasmanian.

Kemampuan emosional anak adalah saat dimana anak dapat mengenali, mengekspresikan, mengerti dan mengelola rentang emosi yang luas. Anak-anak yang dapat mengelola dan mengerti perasaan mereka dengan tetap tenang dan menikmati pengalamannya lebih mungkin untuk mengembangkan citra diri yang positif dan menjadi pribadi yang percaya diri serta penuh rasa ingin tahu dalam belajar. Perkembangan emosional adalah tugas yang kompleks yang dimulai sejak usia dini dan berlanjut sampai ke masa dewasa. 


\section{B. Hakikat Gadget}

Gadget adalah sebuah istilah yang berasal dari bahasa Inggris, yang artinya perangkat elektronik kecil yang memiliki fungsi khusus. Salah satu hal yang membedakan gadget dengan perangkat elektronik lainnya adalah unsur "kebaruan". Artinya, dari hari ke hari gadget selalu muncul dengan menyajikan teknologi terbaru yang membuat hidup manusia menjadi lebih praktis. Gadget adalah piranti yang berkaitan dengan perkembangan teknologi masa kini. Yang termasuk gadget misalnya tablet, smartphone, notebook, dan sebagainya.

Berdasarkan pengalaman penulis, dengan menggunakan Gadget dunia terasa hanya di ujung jari saja, dimana segala bentuk berita terbaru dan informasi dari mana saja akan dapat di akses dan ditemukan hanya dengan Gadget dan akses internet yang serba cepat.

Gadget adalah perangkat elektronik kecil yang memiliki fungsi khusus. Diantaranya smartphone seperti iphone dan blackberry, serta notebook (perpaduan antara komputer portabel seperti notebook dan internet)(Widiawati, $2014: 106$ ).

Dari pendapat tersebut penulis dapat menyimpulkan bahwa, gadget adalah suatu alat elektronik yang memiliki berbagai layanan fitur dan aplikasi yang menyajikan teknologi terbaru yang membantu hidup manusia menjadi lebih praktis dan memiliki fungsi khusus dari masingmasing aplikasi yang ada didalamnya. Maka dari itu, semakin canggih suatu teknologi maka akan lebih banyak dampak negative dan resiko dari penggunaannya, akan lebih fatal jika dalam penggunaannya secara berlebihan dikalangan anak usia dini yang mana dalam penggunaanya tanpa control orang dewasa. 


\section{BAB III \\ PEMBAHASAN}

A. Pengaruh Gadget Terhadap Perkembangan Emosi Anak Usia Dini

Pengaruh penggunaan gadget terhadap perkembangan anak memiliki dampak positif dan dampak negatif. Adapun dampak positifnya antara lain, membantu perkembangan fungsi adaptif seorang anak, menambah pengetahuan anak, memperluas jaringan persahabatan, mempermudah komunikasi, dan membangun kreatifitas anak.

Jika perkembangan zaman sekarang muncul gadget, maka anak pun harus tahu cara menggunakannya karena salah satu fungsi adaptif manusia zaman sekarang adalah harus mampu mengikuti perkembangan teknologi. Sebaliknya, anak yang tidak bisa mengikuti perkembangan teknologi bisa dikatakan fungsi adaptifnya tidak berkembang secara normal. Nilai positif lain adalah gadget memberi kesempatan anak untuk leluasa mencari informasi. Apalagi anak-anak sekolah sekarang dituntut untuk mengerjakan tugas melalui internet.

Sebenarnya kegiatan bermain secara fisik dengan teman sebaya dan orang-orang terdekatnya merupakan kegiatan utama anak yang nampak mulai sejak bayi. Kegiatan ini penting bagi perkembangan kognitif, sosial, dan kepribadian anak pada umumnya. Anak juga bisa mulai memahami hubungan antara dirinya dan lingkungan sosialnya melalui kegiatan bermain, belajar bergaul dan memahami aturan ataupun tata cara pergaulan. Namun sekarang anak lebih banyak menghabiskan waktu dengan bermain gadget daripada bermain dengan teman sebaya, yang bisa menimbulkan sifat individualis dan egosentris, serta tidak memiliki kepekaan terhadap lingkungan sekitar.

B. Dampak negative dan positif dari gadget untuk perkembangan emosional anak:

Dampak pengaruh Gadget pada perkembanan anak sangat banyak. Dampak yang diberikan dari segi pendidikan di Indonesia terbagi dua yaitu, dampak positif dan dampak negatif

Dampak positif:

a. Menambah Pengetahuan dan Kreatifitas

Dengan menggunakan gadget yang berteknologi canggih, anak-anak dengan mudah dan cepat untuk mendapatkan informasi mengenai tugas nya disekoloah. Misalnya kita ingin browsing internet dimana saja dan kapan saja yang ingin kita ketahui. Dengan demikian dari internet kita bias menambah ilmu pengetahuan. Teknologi juga bisa digunakan dengan hal-hal yang baru dan menunjang memicu kreatifitas anak untuk berpikir kreatif. Menurut penulis,anak usia dini seharusnya dijauhkan dari Gadget dan game online karena dapat memicu ketergantungan sehingga anak akan memiliki emosi yang tidak stabil dan ketergantungan, lebih baik anak bermain secara langsung dengan lingkungannya sehingga ia mengenal lingkungan tempat ia berada dan orangorang yang ada dilingkunganya tersebut.

b. Jaringan Persahabatan dan Komunikasi

Gadget dapat memperluas jaringan persahabatan karena dapat dengan mudah dan cepat bergabung ke social media. Jadi, kita dapat dengan mudah untuk berbagi informasi bersama teman kita.Gadget merupakan salah satu alat yang memiliki tekonologi yang canggih. Jadi semua orang dapat dengan mudah berkomunikasi dengan orang lain dari seluruh penjuru dunia. Namun pertemanan di social media sangat tidak cocok untuk anak usia dini, dimana anak memerlukan teman secara nyata dan langsung berinteraksi dengan banyak orang secara langsung agar tercipta hubungan social dan emosional anak terhadap orang lain. 


\section{Dampak negatif:}

a. Mengganggu Kesehatan

Gadget dapat mengaganggu kesehatan manusia karena efek radiasi dari teknologi sangat berbahaya bagi kesehatan manusia terutama pada anak-anak yang berusia 12 tahun kebawah. Efek radiasi yang berlebihan dapat mengakibatkan penyakit kanker, dan juga menganggu kesehatan mental anak ketika mereka menonton fitur-fitur yang belum pantas mereka tonton.

b. Dapat Mengganggu Perkembangan emosi anak

Gadget memilki fiture-fiture yang canggih seperti, kamera, video, games dan lain-lain. Fiture itu semua dapat mengganggu proses pembelajaran di sekolah. Contohnya dirumah seorang anak bermain dengan gadget nya dan orang tua memanggil anaknya namun anak tersebut tidak menghiraukan dan bahkan tidak peduli dengan orang-orang dan kejadian disekitarnya ketika telah asik bermain dengan gadget maka akan berdampak terhadap social emosional anak dengan orangtua nya sendiri.

c. Rawan terhadap tindak kejahatan

Setiap orang pasti ada yang memiliki sifat update di mana saja. Jadi orang ingin berbuat kejahatan dengan mudah mencari nya dari hasil update nya yang boleh dibilang terlalu sering. Menurut yang telah diamati peneliti, anak usia dini cenderung sering menjadi objek dari tindak kejahatan oleh karena orangtuanya sering memamerkan anaknya dan dimana keberadaannya, maka orang lain dengan mudah mengetahui semua hal tentang anaknya dan mudah melakukan kejahatan terhadap anak tersebut, contohnya saja tidak jarang anak artis yang menjadi bahan bullying di social media karena orangtuanya sering pamer dan mengekspos kehidupan anaknya disosial media. Hal tersebut tentu sangat mempengaruhi keadaan mental anak hingga ia dewasa.

d. Dapat Mempengaruhi perilaku Anak

Pada faktanya ada begitu banyak hal yang harus digali lewat proses pembelajaran tradisional dan internet tidak bisa menggantikan kedalaman suatu pengetahuan. Kalau tidak dicermati, maka akan ada kecenderungan bagi generasi mendatang untuk menjadi generasi yang cepat puas dan cenderung berpikir dangkal.

Romo (2013). Menurutnya bermain gadget dalam durasi yang panjang dan dilakukan setiap hari secara kontinyu, bisa membuat anak berkembang ke arah pribadi yang antisosial. Ini terjadi karena anak-anak ini tidak diperkenalkan untuk bersosialisasi dengan orang lain. Selain itu juga berpotensi mendorong anak untuk menjalin relasi secara dangkal. Waktu untuk bercengkerama secara langsung berkurang karena sekarang waktu tersita untuk menikmati semuanya dalam kesendirian. Menurut penulis, Penggunaan gadget yang berlebihan pada anak akan berdampak negatif karena dapat menurunkan daya konsentrasi dan meningkatkan ketergantungan anak untuk dapat mengerjakan berbagai hal yang semestinya dapat mereka lakukan sendiri. Dampak lainnya adalah semakin terbukanya akses internet dalam gadget yang menampilkan segala hal yang semestinya belum waktunya dilihat oleh anak-anak. Banyak anak yang mulai kecanduan gadget dan lupa bersosialisasi dengan lingkungan sekitarnya yang berdampak psikologis terutama krisis percaya diri, juga pada perkembangan fisik anak.

Dari pembahasan tersebut, banyak kita lihat dampak negative dari penggunaan gadget untuk anak usia dini dibandingkan dengan danpak postifnya, (dikutip dalam jurnal Nurhafizah, tahun 2017) menyatakan bahwa guru memiliki peran penting dalam pengembangan potensi anakanak termasuk dalam pengembangan kompetensi sosial emosional. Hanya saja disebahagian taman kanak-kanak, proses pembelajaran masih berpusat pada guru menjadi seorang pendidik dan anak-anak hanya duduk diam menjadi pendengar sehingga peran guru lebih dominan dibandingkan anak, hal tersebut menurut penulis adalah penyebab anak-anak tidak dapat bereklplorasi dengan 
lingkungan sesuai anak usia dini dimana mereka mebutuhkan kebebasan dan keleluasan dalam bermain dengan teman dilingkungan tempat mereka tinggal sehingga mereka mempunyai hubungan emosional dan dapat bersosialisasi. 
A. KESIMPULAN

\section{BAB IV \\ PENUTUP}

Perkembangan emosi pada anak tidak terlepas dari interaksinya dengan lingkungan sosial yang ada disekeliling anak berupa lingkungan sosial yang maya dan tidak pada kenyataannya, maka perkembangan emosi anak pun cendrung tidak ada kuat. Hal ini disebabkan karena umpan balik dari lingkungan virtual yang dapat di atur sesuai dengan kehendak individu, sehingga individu pun harus mengembangkan keteampilan sosial dan emosi untuk mengatasinya. Maka dapat disimuplkan, pengaruh gadget terhadap emosi anak dan kondisi emosi negatif anak yang memungkinkan untuk berkembang menjadi suatu ketergantungan terhadap gadget adalah sebagai berikut:

a. Kecemasan, yaitu apabila gadget, komputer dan lainnya dapat digunakan untuk mengalihkan perhatian dari kecemasan anak, maka yang teerjadi justru individu tersebut semakin tidak mampu mengatasi kecemasannya dan sebaliknya bahkan bisa jadi akan semakin kecanduan

b. Depresi, untuk semetntara mungkin di alihkan dengan aktivitas anak dalam mengakses internet menggunakan gadget. Selain aspek emosi yang dapat menimbulkan kecendrungan anak.Begitu banyak dampak negative dari penggunaan Gadget bagi perkembangan emosional anak usia dini,

Menurut penulis, anak usia dini seharusnya dijauhkan dari Gadget dan game online karena dapat memicu ketergantungan sehingga anak akan memiliki emosi yang tidak stabil dan ketergantungan, lebih baik anak bermain secara langsung dengan lingkungannya sehingga ia mengenal lingkungan tempat ia berada dan orang-orang yang ada dilingkunganya tersebut. 


\section{REFERENSI}

Ahmad Zain. (2012). http://edukasi.kompasiana.com/2012/02/18/sto p-fenomena-anak-di-bawahumur-melanggarhukum. jakarta: kompasiana.

Daniel Goleman. (2006). Emotional Intelligence, terjemahan cetakan ke 22. jakarta: gramedia pustaka utama.

Drajat Edy Kurniawan. (2017). Pengaruh Intensitas Bermain Game Online Terhadap Perilaku Prokrastinasi Akademik Pada Mahasiswa Bimbingan dan Konseling Universitas PGRI Yogyakarta. Jurnal Koseling Gusjigang, 3(1), 1-8. Retrieved from http://jurnal.umk.ac.id/index.php/gusjigang/article/download/1120/1071

Evaporation, I. (2017). Evaluation of Temperature and Pressure of Ablation Plasma in an Intense, Pulsed, Ion-Beam Evaporation, 6(2), 244-247.

Hazizah, N. (2018). The Importance of Playing for Developing Intelligence in Early Childhood, 169(Icece 2017), 213-215.

Jhon W Santrock. (2007). Remaja Edisi 11 Jilid 1. jakarta: erlangga.

Ma, J. (2018). Analysis of The Development Gross Motor and Emotional-Social Skills in Terms of Characteristics of Parents in Kindergarten Children, 173(Icei 2017), 152-155.

Moh, A. (2017). The Development of Children 's Social -Emotional Competences : A Case Study in UNP' s Labschool -Kindergarten, Padang Indonesia, 58, 369-374. 